\title{
Faktor Penentu Permintaan Agrowisata Kopi di Jawa Timur
}

\author{
Sri Tjondro Winarno ${ }^{1)^{*}}$, Wiwik Sri Harijani ${ }^{2)}$, Laksmi Diana ${ }^{3)}$ \\ Setyo Parsudi ${ }^{4}$ \\ ${ }^{1)}$ Prodi Agribisnis Fakultas Pertanian UPN Veteran Jawa Timur \\ ${ }^{2}$ Prodi Agriteknologi Fakultas Pertanian UPN Veteran Jawa Timur \\ email : sritjondro w@upnjatim.ac.id ${ }^{1)^{*}}$, wiwik sh@upnjatim.ac.id ${ }^{2)}$, \\ setyoparsudi@gmail.com ${ }^{3)}$, laksmidiana.agribis@upnjatim.ac.id ${ }^{4)}$
}

\begin{abstract}
Abstrak
Tujuan penelitian ini adalah untuk menganalisis faktor-faktor yang mempengaruhi agrowisata kopi di Jawa Timur (personal, budaya, lingkungan sosial, psikologi). Penelitian dilakukan di 19 kabupaten di Provinsi Jawa Timur. Jumlah responden dalam penelitian ini sebanyak 285, setiap kecamatan diambil sebanyak 15 responden. Analisis menggunakan software (Soft Ware) WarpPLS 6.0 (Partial Least Squares). Hasil penelitian menunjukkan bahwa variabel personal, budaya, lingkungan sosial, psikologi memberikan pengaruh positif nyata terhadap permintaan wisatawan agrowisata kopi di Jawa Timur.
\end{abstract}

Kata Kunci: Personal, Budaya, Lingkungan Sosial, Psikologi, Agrowisata Kopi.

\section{Pendahuluan}

Pariwisata terbukti mampu mendorong pertumbuhan perekonomian melalui peluang investasi, peluang kerja, peluang berusaha dan pada akhirnya akan dapat meningkatkan kesejahteraan masyarakat.

Pelaksanaan pembangunan yang berorientasi kepada peningkatan kesejahteraan masyarakat mempunyai dampak terhadap lingkungan sekitarnya baik secara langsung maupun tidak langsung. Pengelolaan lingkungan dan obyek wisata itu sangat mempengaruhi kelestarian fungsi lingkungan dan obyek wisata itu sendiri dapat menimbulkan dampak positip maupun negatip. Di Jawa Timur industri agrowisata kopi ini sudah mulai tumbuh dan berkembang. Dimana masingmasing daerah yang mempunyai perkebunan kopi yang dikelola rakyat namun demikian ada beberapa daerah yang sudah mulai mengembangkan agrowisata kopi ini dengan cara yang berbeda antara satu daerah dengan daerah yang lain. Wibowo (2007), secara umum grand strategi dalam pembangunan perkebunan kopi di Jawa Timur diperukan konsolidasi dengan semua sumberdaya yang ada, meliputi sumberdaya lahan, teknologi budidaya, pengolahan serta alternative pengembangan produk dan pemasaran. Proses selanjutnya produk industry pariwisata pemerintah dan perusahaan biro perjalanan wisata sebagai perencana dan penyusun dan pengembangan pariwisata. Jadi produk final industri pariwisata itu merupakan gabungan dari berbagai macam produk yang dihasilkan oleh beberapa perusahaan yang memberikan pelayanan secara langsung kepada wisatawan bila 
melakukan perjalanan wisata (Yoeti, 2008).Habibi, Rahmati, Karimi (2018), sektor pariwisata memberikan dampak yang positif terhadap pertumbuhan ekonomi di Iran.Mantymaa, Tyrvainen, Juutinen, Kurttila (2019), perusahaan pariwisata berbasis alam memiliki potensi lebih besar untuk mendapatkan pemasukan dari wisatawan.Winarno $\quad d k k \quad$ (2018) mengemukakan bahwa keunggulan kompetitif akan sangat berkaitan dengan faktor internal dan eksternalGugushvili, Salukvadze, Salukvadze (2017), pertumbuhansektor pariwisata yang pesat memicu pertumbuhan ekonomi, tetapi cabang ekonomi yang lain seperti pertanian, perdagangan juga harus dilibatkan dalam kegiatan pariwisata ini. Utami, Setyaningsih, Winarto (2020), perencanaan agrowisata kopi merupakan gabungan ataspemanfaatan unsur air, pemanfaatan unsur udara, pemanfaatan unsur tanah, dan pemanfaatan unsur energy. Dewi, Hernawan, Mustofa (2019),di kawasan wisata edukasi kopi Palasari. Selain itu perlu juga akses transportasi yang memadai, merchandise, dan pelayanan jasa lainnya yang bersifat keterbaruan serta memiliki karakteristikyang berbeda. Rusadi, Purwatiasning, Satwikasari (2019), penerapan konsep wisata edukasi memungkinkan pengunjung mendapatkan kenikmatan sebuah perjalanan wisata dan mengeksplorasi kopi. Gunawan, Yunita, Zakaria (2016), kondisi alam sebagai salah satu daya tarik unggulan di desa Warjabakti sangat menunjang untuk pengembangan pariwisata. Purnomo dan Mintorogo (2019), desain dengan pendekatan sustainable design mengenalkan Kopi Arabika Kintamani kepada masyarakat luas, dengan demikian akan tetap memperhatikan kearifan lokal dan lingkungan sentra pertanian Kintamani. Dwiridotjahjono, Arifin, Sasongko, Maroeto, Santoso (2017), penguatan kelembagaan pengembangan agrowisata dilakukan dengan peningkatan hubungan kelembangaan antara pengusahaan agrowisata, usaha rumah tangga, agroindustri pendukung, serta lembaga pembiayaan dan pengembangan bisnis yang terkait.

Tujuan daripada penelitian ini adalah untuk menganalisis pengaruh pribadi, lingkungan social, budaya, psikologi, terhadap permintaan wisatawan agrowisata kopi di Jawa Timur.

\section{Metode Penelitian}

Daerah yang digunakanuntuk penelitian ditentukan secara sengaja (Purposive), yaitu di wilayah Provinsi Jawa Timur dan yang memiliki areal perkebunan kopi. Lokasi yang digunakan sebagai obyek penelitian meliputi 19 Kabupaten diantaranya Banyuwangi, Situbondo, Bondowoso, Jember, Lumajang, Pasuruan, Malang, Jombang, Mojokerto, Nganjuk, Kediri, Tulung Agung, Blitar, Trenggalek, Madiun, Ngawi, Magetan, Ponorogo, dan Pacitan. Jumlah responden dalam penelitian ini sebanyak 285, setiap Kabupaten diambil sebanyak 15 responden, respondennya diantaranya adalah petani kopi, pelaku usaha kopi, masyarakat yang tinggal disekitar lokasi pariwisata berbasis kopi, Dinas pertanian, Dinas Pariwisata, Konsumen kopi. Analisis yang digunakan untuk menjawab 
penelitian ini dengan menggunakan Structural Equation Model (SEM) yang juga dinamakan Model Persamaan Struktural (MPS) dengan menggunakan piranti lunak (Soft Ware) WarpPLS 6.0 (Partial Least Squares). Kock (2016), PLS-SEM telah mengalami pertumbuhan yang mantap di bidang e-kolaborasi pada bidang yang banyak dimana statistik multivariat digunakan. Salah satu alasannya adalah munculnya perangkat lunak yang hebat dan mudah digunakan untuk PLS-SEM, seperti WarpPLS.

\section{Hasil dan Pembahasan}

Berdasarkan pengolahan data menggunakan WarpPLS. 6.0 dapat dilihat pada Tabel 1.

\begin{tabular}{|c|l|c|c|c|c|c|}
\hline \multicolumn{2}{|c|}{ HASIL STUDI BERBASIS PENGOLAHAN DATA MENGGUNAKAN WARP PLS } \\
\hline Hipotesis & \multicolumn{1}{|c|}{ Path } & $\begin{array}{c}\text { Path } \\
\text { Coefficient }\end{array}$ & $\begin{array}{c}\text { P } \\
\text { Values }\end{array}$ & $\begin{array}{c}\text { Standart } \\
\text { of Error } \\
\text { for Path } \\
\text { Coefficient }\end{array}$ & $\begin{array}{c}\text { Effect Size } \\
\text { For Path } \\
\text { Coefficient }\end{array}$ & Sig \\
\hline$H_{1}$ & $\begin{array}{l}\text { Pribadi-> Permintaan } \\
\text { Wisata Agrowisata Kopi }\end{array}$ & 0.141 & 0.008 & 0.058 & 0.086 & $\begin{array}{c}\text { p<0.05 } \\
\text { Significant } \\
\left(H_{1}\right. \\
\text { accepted })\end{array}$ \\
\hline$H_{2}$ & $\begin{array}{l}\text { Lingkungan Sosial -> } \\
\text { Permintaan Wisata } \\
\text { Agrowisata Kopi }\end{array}$ & 0.447 & $<0.001$ & 0.055 & 0.379 & $\begin{array}{c}\text { p<0.05 } \\
\text { Significant } \\
\left(H_{2}\right. \\
\text { accepted }\end{array}$ \\
\hline$H_{3}$ & $\begin{array}{l}\text { Budaya -> Permintaan } \\
\text { Wisata Agrowisata Kopi }\end{array}$ & 0.100 & 0.044 & 0.058 & 0.039 & $\begin{array}{c}\text { p }>0.05 \\
\text { Non } \\
\text { Significant } \\
\left(H_{3} a c c e p t e d\right. \\
)\end{array}$ \\
\hline$H_{4}$ & $\begin{array}{l}\text { Psikologi -> Permintaan } \\
\text { Wisata Agrowisata Kopi }\end{array}$ & 0.114 & 0.025 & 0.058 & 0.079 & $\begin{array}{c}\text { p<0.05 } \\
\text { Significant } \\
\left(H_{4}\right. \\
\text { accepted })\end{array}$ \\
\hline
\end{tabular}

\section{Pribadi}

Berdasarkan hasil analisis Warp. PLS 6.0, maka pribadi berpengaruh positif yang nyata terhadap permintaan wisatawan pada agrowisata kopi di Jawa Timur (Y) dengan nilai koefisien jalur sebesar 0.141 dimana nilai $\mathrm{p}=0.008<0.05$. Dimana dari total 285 responden yang terlibat dalam penelitian ini responden pria sebanyak 165 orang atau $57,89 \%$ sedangkan responden wanita sebanyak 120 orang atau $42,10 \%$, terdapat perbedaan sebesar 45 responden. Dari sisi usia maka yang berusia antara 35 - 50 tahun sebanyak 225 responden atau 78,95 $\%$, kemudian yang berpendidikan
SMA keatas sebanyak 260 responden atau $91,23 \%$ sisanya berpendidikan SD dan SMP sebanyak 25 responden. Saat ini semakin banyak munculnya café-café kopi terutama di daerah perkotaan dan di daerah pedesaan, maka daerah yang memiliki perkebunan kopi ada kecenderungan membangun dan mengembangkan agrowisata kopi di Jawa Timur. Pada satu sisi banyaknya para penikmat kopi cenderung memilih suasana yang baru dan bisa bersama keluarga untuk menikmati kopi ini dalam suasana yang baru, alami, aman, nyaman, fasilitas yang memadai serta aksesnya mudah. Barkhi, Wallace (2007), persepsi 
dan sikap dapat meningkatkan konsumen dalam pembeliannya. Reynolds (2013), perilaku ekonomi diengaruhi oleh etika, nilai peran dan jaringan lokal. Golding and Peattie (2005), pemasaran sosial memilikikontribusi yangefektif terhadap perilaku. Nadeema, Juntunena, Shirazib, Hajlic(2020), bahwa dukungan sosial mempengaruhi persepsi, kepercayaan konsumen, kepuasan dan komitmen.

\section{Budaya}

Berdasarkan hasil analisis Warp. PLS 6.0, maka pribadi berpengaruh positip yang nyata terhadap permintaan wisatawan pada agrowisata kopi di Jawa Timur (Y) dengan nilai koefisien jalur sebesar 0.100 dimana nilai $\mathrm{p}=0.044<0.05$. Masyarakat di Jawa Timur itu mempunyai adat istiadat dan ragam budaya yang banyak sekali. keberagaman adat istiadat tersebut sampai sekarang masih dijaga keberadaannya sehingga masyarakat di Jawa Timur memiliki kesantunan dan kebersamaan berjalan dengan baik. Bahkan daerah tertentu memiliki budaya yang sampai sekarang masih dipertahankan sehingga masyarakat sangat menghormati budayanya demikian juga dengan masyarakat dari daerah lain. Kondisi ini secara otomatis memudahkan untuk melakukan pembangunan serta pengembangan pariwisata dimana masyarakat akan tetap menjaga warisan budaya yang ada didaerah masing-masing. Disatu sisi masyarakat di Jawa Timur sejak dahulu mengkonsumsi kopi itu sudah merupakan kebiasaan yang turun temurun, sehingga kebiasaan ini merupakan modal yang sangat baik berkaitan dengan agrowisata kopi di Jawa Timur ini. Calza, Cannavale, Nadali (2020), nilai budaya berperan dalam proses penalaran kegiatan kewirausahaan. Sands, Ferraroa, Campbell, Kietzmann, Andonopoulos (2020), norma-norma sosial dapat digunakan sebagai bentuk pengaruh sosial dan mendorong konsumen untuk terlibat dalam tingkat konsumsi bersama yang lebih tinggi.

\section{Lingkungan Sosial}

Berdasarkan hasil analisis Warp. PLS 6.0, maka pribadi berpengaruh positip yang nyata terhadap permintaan wisatawan pada agrowisata kopi di Jawa Timur (Y) dengan nilai koefisien jalur sebesar 0.447 dimana nilai $\mathrm{p}=<0.001<0.05$. Agrowisata merupakan gabungan antara beberapa sumberdaya yang diantaranya sumberdaya alam dengan sumberdaya yang diciptakan oleh manusia seperti sarana dan prasarana yang menunjang adanya obyek agrowisata kopi tersebut. Berdasarkan pengamatan dilapang saat melakukan penelitian, maka factor keluarga dalam hal ini sebagian besar yang menentukan berwisata adalah kepala keluarga, walaupun pada kasus tertentu tidak tergantung kepada kepala keluarga. Beberapa diantaranya menghendaki adanya lokasi wisata, kemudahan aksesnya, lokasinya nyaman, terjamin keamanannya serta mempunyai banyak produk yang ditawarkan.

Stampa, Schipmann-Schwarze, Hamm (2020), pemahaman tentang sistem produksi untuk produk organik atau konvensional. Ini membutuhkan pengetahuan untuk komunikasi masalah manfaat lingkungan dan sosial. Srihadia, Setiawan (2015), bahwa kepercayaan diri merupakan manfaat terpenting yang dipertimbangkan konsumen dalam membangun hubungan jangka 
panjang dengan penyedia layanan. Kumagai, Nagasawa (2019), bahwa prestise lokasi, lokasi yang ideal terhadap factor social memberikan kontribusi positif terhadap sikap konsumen terhadap merek barang mewah. Pena-Garcia, Gil-Saura, Rodríguez-Orejuela, Siqueira-Junior (2020), terdapat perbedaan yang substansialpertimbangan utama dalam membeli secara on line antara konsumen negara berkembang dengan negara maju.Xhema (2019), bahwa ada hubungan negatif antara penggunaan media sosial dan pelanggan loyalitas terdapat hubungan yang negatip dimana jejaring sosial memengaruhi perilaku pelanggan.

\section{Psikologi}

Berdasarkan hasil analisis Warp. PLS 6.0, maka pribadi berpengaruh positip yang nyata terhadap permintaan wisatawan pada agrowisata kopi di Jawa Timur (Y) dengan nilai koefisien jalur sebesar 0.114 dimana nila $\mathrm{p}=0.025<0.05$. Kebutuhan yang bersifat psikologi merupakan kebutuhan yang muncul dari kondisi tertentu, seperti kebutuhan untuk diakui eksisitensinya, diakui jati dirinya serta diakui dapat diterima dilingkungan lama maupun dilingkungan barunya. Agrowisata kopi merupakan wisata yang berbasis komoditas tanaman kopi serta olahannya, maka dalam pengelolaannya harus dilakukan secara professional. Dengan demikian akan memberikan persepsi yang baik kepada agrowisata kopi di Jawa Timur ini, dengan pengetahuan yang baik misalkan kemampuan berbahasa asing, sikap yang ramah tamah, jaminan produk yang menyehatkan serta pengetahuan dalam budidaya kopi beserta olahannya akan menjadi daya Tarik tersendiri.Wang (2017), menyampaikan bahwa identitas sosial memiliki beberapa dimensi yang meliputi kognitif, afektif, dan evaluative, pengaruh ketiga dimensi tersebutterhadap perilaku penggunaan dan pembelian memiliki pengaruh yang beragam. Cetina, Munthiu, Radulescu (2012), banyak faktor yang memainkan peran kunci dalam perilaku konsumen virtual diantaranya, signifikansi, karakteristik, kekhususan faktor psikologis dan sosial.

\section{Kesimpulan dan implikasinya}

Berdasarkan hasil penelitian meunjukkan bahwa factor pribadi, budaya, lingkungan social, psikologi, factor pendukung, factor penghambat memberikan pengaruh yang positip yang nyata. Lebih lanjut dari hasil penelitian ini dapat memberikan implikasi praktis, mengingat komoditas kopi mempunyai prospek yang bagus. Oleh karena itu pengembangan industry pariwisata dalam hal ini agrowisata kopi diharapkan data memberikan harapan baru bagi para penikmat kopi. Dimana jika ingin menikmati kopi bersama keluarga dalam suasana yang berbeda maka akan dapat mendorong daerah-daerah lai yang belum mempunyai agrowisata kopi bisa segera untuk dilakukan pembangunan dan pengembangannya.

\section{Daftar Pustaka}

Barkhi, R. Wallace, L. (2007), "The Impact Of Personality Type on Purchasing Decisions In Virtual Stores". Inf Technol Manage. No. 8, pp. 313-330.

Calza, F. Cannavale, C. Nadali, I.Z. (2020), "How do cultural 
values influence

entrepreneurial behavior of nations? A behavioral reasoning approach". International Business Review. $\mathrm{xxx}$ :xxxx (article in press).

Cetina, I. Munthiu, M.C. Radulescu, V. (2012), "Psychological and social factors that influence online consumer behavior". Procedia - Social and Behavioral Sciences. Vol. 62, pp. $184-188$. WCBEM 2012.

Dewi, S.W. Hernawan, K. Mustofa, Y. (2019), "Pelatihan Pengembangan Strategi Pemasaran Kopi Palasari Melalui Pembuatan Video Kreatif di Kampung Wisata Edukasi Kopi Palasari Bandung". JURNAL ABDIMAS BSI Jurnal Pengabdian Kepada Masyarakat. Vol. 2, No. 1, pp. 105-117.

Dwiridotjahjono, J. Arifin, A.J. Sasongko P.E. Maroeto. Santoso, W. (2017), "Pengembangan

Agroekowisata Berbasis Perkebunan Kopi Rakyat di Kecamatan Tutur, Kabupaten Pasuruan". Agrokreatif Jurnal Ilmiah Pengabdian kepada Masyarakat. Vol. 3, No. 2, pp. 157-165.

Golding, K., \& Peattie, K. (2005), "In search of a golden blend: Perspectives on the marketing of fair trade coffee. Sustainable Development". Vol.13, No. 3, pp. 154-165.

Gugushvili, T. Salukvadze, G. Salukvadze, J. (2017),
"Fragmented development: Tourism-driven economic changes in Kazbegi, Georgia". AnnalsofAgrarianScience. No. 15, pp. 49-54.

Gunawan, W. Yunita, D. Zakaria, S. (2016), "Pengembangan wisata kopi berbasis masyarakat di Desa Warjabakti Kabupaten Bandung". SOSIOGLOBAL Jurnal Pemikiran dan Penelitian Sosiologi. Vol. 1, No. 1, pp. 33-48.

Habibi, F. Rahmati, M. Karimi, A.C. (2018), "Contribution of tourism to economic growth in Iran's Provinces: GDM approach". Future Business Journal. No. 4, pp. 261-271.

Kock, N. (2016), "Hypothesis testing with confidence intervals and $\mathrm{P}$ values in PLSSEM". International Journal of e-Collaboration. No. 12, pp. 1-6.

Kumagai, K. Nagasawa, S. (2019), "Psychological switching mechanism of consumers' luxury and non-luxury brand attitude formation: the effect of store location prestige and selfcongruity". Heliyon. Vol. 5, pp. 01518.

Mantymaa, E. Juutinena, A. Tyrvainen, L. Karhu, J. Kurttilad, M. (2018), "Participation and compensation claims in voluntary forest landscape conservation: The case of the Ruka-Kuusamo tourism area, 
Finland". Journal of Forest Economics. No. 33, pp.14-24.

Nadeema V. Juntunena, M. Shirazib, F. Hajlic, N. (2020), 'Consumers' value co-creation in sharing economy: The role of social support, consumers' ethical perceptions and relationship quality". Technological Forecasting and Social Change.Vol. 151, pp. 119786.

Pena-Garcia, N. Gil-Saura, I. Rodríguez-Orejuela, A. Siqueira-Junior, J.R. (2020), "Purchase intention and purchase behavior online: A cross-cultural approach". Heliyon. Vol. 6, pp. 04284.

Reynolds, A. (2013), "Networks, Ethics, And Economic Values : Faith-Based Business and the Coffee Trade in Central America". Latin American Research Review. Vol. 48, No. 1, pp. 112-132.

Rusadi, P. Purwatiasning, A.W. Satwikasari, A.F. (2019), "Penerapan konsep arsitektur hijau pada perencanaan agrowisata kopi di temanggung". Jurnal Arsitektur PURWARUPA. Vol.03, No. 4, pp. 25-30.

Sands, S. Ferraroa, C. Campbell, C. Kietzmann, C. Andonopoulos, V.V. (2020), "Who shares? Profiling consumers in the sharing economy" Australasian Marketing Journal. $\operatorname{xxxx}: \operatorname{xxxx}$ (article in press).
Srihadia, S.F. Setiawan, D. (2015), "The Influence of Different Level of Service Characteristics and Personal Involvement towards Consumer Relational Response Behaviors". Procedia - Social and Behavioral Sciences. Vol. 210, pp. 378 - 387. 4th International Conference on Leadership, Technology, Innovation and Business Management.

Stampa. E, Schipmann-Schwarze. C, Hamm, U. (2020), "Consumer perceptions, preferences, and behavior regarding pastureraised livestock products: A review". Food Quality and Preference. Vol. 82, pp. 103872.

Utami, N.A. Setyaningsih, W. Winarto, Y. (2020), "Penerapan arsitektur ekologis pada perencanaan agrowisata kopi di Desa Serang, Purbalingga"SENTHON $G$. Vol. 3, No. 1, pp. 136- 145 .

Wang, T. (2017), "Social identity dimensions and consumer behavior in social media Asia Pacific Management Review". Vol.22, Issue 1, pp. 45-51.

WibowoR. (2007),

Revitalisasikomoditas unggulan perkebunan Jawa Timur. PERHEPI. Jakarta.

Winarno, S. T., Darsono, Harisudin, M., \& Sudiyarto. 2018. Competitiveness Analysis of Robusta Coffee in East Java, 
Indonesia. Academy of Strategic

Management Journal. 17(6): 1-9.

Xhema, J. (2019), "Effect of Social Networks on Consumer

Behaviour: Complex Buying”.

IFAC PapersOnLine Vol. 52, No. 25, pp. 504-508.

Yoeti, O.A. (2008), Perencanaan dan pengembangan pariwisata. Penerbit PT Pradnya Paramita. Jakarta. 